\title{
Varied presentation of lobar holoprosencephaly as a cause of macrocephaly in a neonate
}

\author{
Amruta Varma (D) ,' Gaurav Vedprakash Mishra (D) ,' Rajasbala Dhande, ${ }^{2}$ \\ Bhushita B Lakhkar ${ }^{3}$
}

${ }^{1}$ Department of Radio-Diagnosis, Datta Meghe Institute of Medical Sciences-Wardha Campus, Wardha, India ${ }^{2}$ Radiodiagnosis, Datta Meghe Institute of Medical SciencesWardha Campus, Wardha, Maharashtra, India ${ }^{3}$ Radiology, Datta Meghe Institute of Medical SciencesWardha Campus, Wardha, Maharashtra, India

Correspondence to Dr Gaurav Vedprakash Mishra; gaurav.mishra@dmimsu.edu.in

Accepted 17 December 2021

Check for updates

(c) BMJ Publishing Group Limited 2022. No commercial re-use. See rights and permissions. Published by BMJ.

To cite: Varma A, Mishra GV, Dhande $\mathrm{R}$, et al. BMJ Case Rep 2022;15:e248024. doi:10.1136/bcr-2021248024

\section{DESCRIPTION}

A 37 weeks primigravida presented in obstetric department with the report of labour pain. She had undergone antenatal scans two times; first scan in first trimester and second in third trimester. In the antenatal sonography at around 30 weeks, the fetus was diagnosed with hydrocephalus and macrocephaly, as the head circumference was $31.5 \mathrm{~cm}$, which is $>97$ percentile for gestational age. ${ }^{1}$ On examination, the cervix was $4 \mathrm{~cm}$ dilated and the fetal head was not engaged. Considering the risk of fetal distress and the presence of macrocephaly, the patient was taken for caesarean section and the baby was delivered at 37 weeks. The baby was admitted in Neonatal Intensive Care Unit (NICU) care in view of hyperbilirubinemia, serum bilirubin was $26.1 \mathrm{mg} / \mathrm{dL}$, for which the phototherapy was given. On clinical examination, the newborn had occipitofrontal circumference of $41 \mathrm{~cm},>97$ percentile for the age ${ }^{2}$ and suggestive of macrocephaly. The baby also had downward gaze, frontal bossing and was lethargic (figure 1). After 2 weeks, the bilirubin levels were within normal limits and the patient was advised MRI to rule out the cause of hydrocephalus. On MRI, the findings of lobar holoprosencephaly with enlargement of arachnoid space were present: cavum septum was absent and frontal horn of lateral ventricles were fused giving a 'box-shaped appearance'. ${ }^{3}$ Interhemispheric fissure and falx were present. There was partial fusion of thalamus. Grey matter and white matter were well appreciated with no gross atrophy of brain parenchyma. All these features were suggestive of lobar-type holoprosencephaly. ${ }^{4}$ However, along with this, there were features of gross enlargement of subarachnoid space characterised by fluid

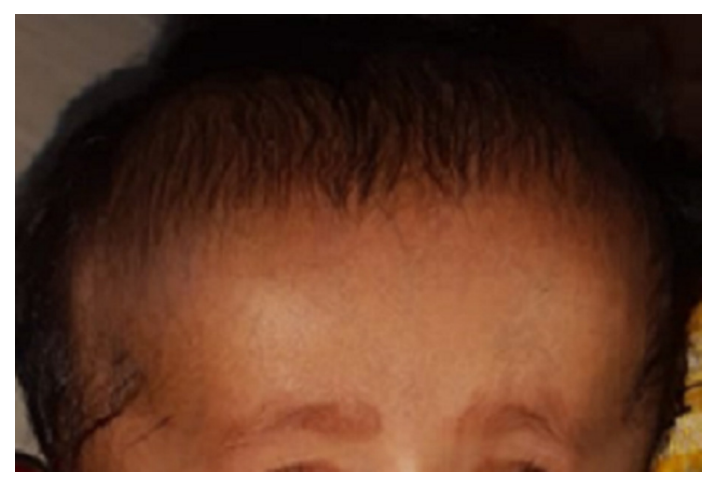

Figure 1 Neonate presenting with gross macrocephaly and frontal bossing. No other external anomalies were present.

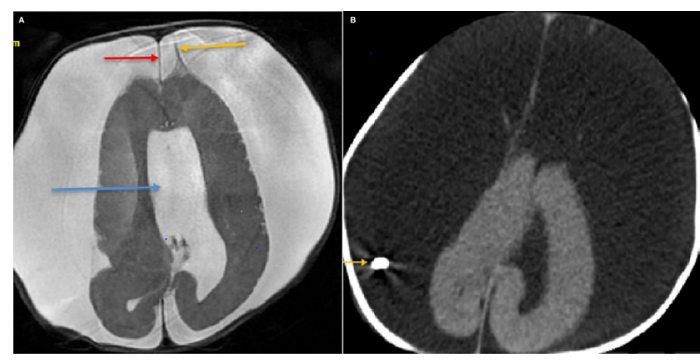

Figure 2 (A) T2-weighted image on MRI showing the presence of falx cerebri anteriorly (red arrow), absent cavum septum and box-shaped fused frontal horns of lateral ventricles (blue arrow) and traversing vessel across the subarachnoid fluid collection giving cortical vein sign(yellow arrow). (B) Post ventriculo-peritoneal shunting CT image, showing the tip (arrow) of the ventricular end in the enlarged subarachnoid space.

collection, which was similar to CSF intensity on all the MRI sequences, that is, hyperintense on T2WI and suppressed on FLAIR sequence. A vessel traversing through this fluid collection was present, suggestive of the 'cortical vein sign', 5 thus, causing the external hydrocephalus (figure 2 ). ${ }^{6}$ Following this, peritoneal shunting of the fluid from the external hydrocephalus caused due to the enlarged subarachnoid spaces was done. Post drainage, there was a decrease in head circumference, occipitofrontal circumference was $38 \mathrm{~cm}$. The parents were advised genetic testing for the baby as well as themselves, however, due to lack of financial support, it was not done. The parents were advised regarding the importance of timely antenatal scan as well, in case of future pregnancy.

\section{Patient's perspective}

Translated from patient's mother's language:

As soon as the labour pain started, I was referred to the hospital where I delivered the baby. Post the birth of my baby, we noticed her head was enlarged, for which the doctor advised MRI. The doctor informed us that the baby had an enlarged head due to the collection of fluid and for which shunting was done. I know that this is not common and that the baby will have to be dependent on others and have difficulty in performing routine activities as she grows. I feel privileged hoping that my baby's story can help some other baby and the parents who are suffering from the same. 


\section{Learning points}

- In case of holoprosencephaly, the cause of macrocephaly is usually internal hydrocephalus; however, in this case, it was the external hydrocephalus associated with holoprosencephaly as an underlying cause of macrocephaly.

- Surgical shunting proved to be a life-saving procedure in the present case where macrocephaly was unconventionally caused due to external hydrocephalus. The proximal and distal tip of the shunt were placed in subarachnoid space and peritoneal cavity, respectively.

Acknowledgements I would like to thank Dr Sachin Yedve, Dr Soumya Jain and Dr Subramanyam, who were involved in the patient care as well as in providing the clinical details of the patient.

Contributors AV was involved in planning and reporting the work. GVM has contributed in editing and formulating the case report. RD and BBL have contributed in preparing the case report.

Funding The authors have not declared a specific grant for this research from any funding agency in the public, commercial or not-for-profit sectors.

Competing interests None declared.

Patient consent for publication Consent obtained from parent(s)/guardian(s)
Provenance and peer review Not commissioned; externally peer reviewed.

Case reports provide a valuable learning resource for the scientific community and can indicate areas of interest for future research. They should not be used in isolation to guide treatment choices or public health policy.

\section{ORCID iDs}

Amruta Varma http://orcid.org/0000-0001-5696-6304

Gaurav Vedprakash Mishra http://orcid.org/0000-0003-4957-7479

\section{REFERENCES}

1 Kiserud T, Piaggio G, Carroli G, et al. The world Health organization fetal growth charts: a multinational longitudinal study of ultrasound biometric measurements and estimated fetal weight. PLOS Med 2017;14:e1002220.

2 Grummer-Strawn LM, Reinold C, Krebs NF, et al. Use of World Health organization and CDC growth charts for children aged 0-59 months in the United States. MMWR Recomm Rep 2010:59:1-15.

3 Winter TC, Kennedy AM, Woodward PJ. Holoprosencephaly: a survey of the entity, with embryology and fetal imaging. Radiographics 2015;35:275-90.

4 Sikakulya FK, Kiyaka SM, Masereka R, et al. Alobar holoprosencephaly with Cebocephaly in a neonate born to an HIV-positive mother in eastern Uganda. Case Rep Otolaryngol 2021;2021:1-4.

5 Kuruvilla LC. Benign enlargement of sub-arachnoid spaces in infancy. J Pediatr Neurosci 2014;9:129

6 Marino MA, Morabito R, Vinci S, et al. Benign external hydrocephalus in infants. Neuroradiol J 2014;27:245-50.

Copyright 2021 BMJ Publishing Group. All rights reserved. For permission to reuse any of this content visit

https://www.bmj.com/company/products-services/rights-and-licensing/permissions/

BMJ Case Report Fellows may re-use this article for personal use and teaching without any further permission.

Become a Fellow of BMJ Case Reports today and you can:

- Submit as many cases as you like

- Enjoy fast sympathetic peer review and rapid publication of accepted articles

- Access all the published articles

Re-use any of the published material for personal use and teaching without further permission

\section{Customer Service}

If you have any further queries about your subscription, please contact our customer services team on +44 (0) 2071111105 or via email at support@bmj.com.

Visit casereports.bmj.com for more articles like this and to become a Fellow 